ISSN: 2526-7884

Editor: Prof. Dr. Marconi Freitas da Costa

E-mail: cbr@ufpe.br
Evaluation: Double blind review

Received: July 29, 2021

Approved: January 03, 2022

\title{
RELEVANT ATTRIBUTES FOR OLIVE OIL PURCHASING DECISIONS: A COMPARISON BETWEEN BRAZIL AND PORTUGAL
}

Atributos Relevantes para Decisões de Compra de Azeite: Uma comparação entre Brasil e Portugal

\author{
Marcela de Oliveira e Silva Loureiro ${ }^{1}$ \\ ORCID: https://orcid.org/0000-0002-2336-4937 \\ E-mail: celaloureiro@gmail.com \\ Natália Araujo Pacheco \\ ORCID: https://orcid.org/0000-0001-5607-9326 \\ E-mail: natalia.pacheco@ipam.pt \\ Janaína Carla Kovalski \\ ORCID: https://orcid.org/0000-0001-6112-5737 \\ E-mail: janainack@outlook.com \\ ${ }^{1,2}$ Instituto Português de Administração de Marketing de Lisboa, Lisboa, Portugal \\ ${ }^{2,3}$ Faculdade Meridional IMED, IMED Business School, Porto Alegre, Brasil
}

\begin{abstract}
Objective: To identify and compare the most relevant attributes for consumers when deciding to buy olive oil in Brazil and Portugal. Method: In the first study, 10 olive oil consumers were interviewed to understand and identify the attributes that influence the
\end{abstract}

\begin{abstract}
Resumo
Objetivo: Identificar e comparar os atributos mais relevantes para os consumidores na decisão de compra de azeites no Brasil e em Portugal.

Método: No primeiro estudo, foram entrevistados 10 consumidores de azeite para
\end{abstract}


decision process. In the second study, a survey was conducted with 338 consumers to compare the importance of the attributes.

Findings: Taste, type of olive oil, acidity and price were among the five most important attributes for both nationalities, along with brand (only for Brazilians) and country of origin (only for Portuguese). Among the most important attributes, price was the least important and was used as a tie-breaker between similar products.

Originality: Despite the economic importance of this market (€856 million in 2019), little is known about the attributes that are most relevant to consumers. This research provides current information on these attributes.

Keywords: purchase intention; country of origin; brand; acidity. compreender e identificar os atributos que influenciam o processo de decisão. No segundo estudo, foi realizada uma survey com 338 consumidores para comparar a importância dos atributos.

Descobertas: 0 sabor, o tipo de azeite, o grau de acidez e o preço estiveram entre os cinco atributos mais importantes para ambas as nacionalidades, juntamente com a marca (só para os brasileiros) e com o país de origem (só para os portugueses). Dentre os atributos de maior importância, o preço foi o de menor relevância, sendo utilizado como um critério de desempate entre produtos semelhantes.

Originalidade: Apesar da importância econômica desse mercado (€856 milhões em 2019), pouco se sabe sobre os atributos mais relevantes para os consumidores. A presente pesquisa traz informações atuais sobre esses atributos.

Palavras-chave: intenção de compra; país de origem; marca; acidez.

This work is licensed under a Creative Commons Attribution 4.0 International License: https://creativecommons.org/licenses/by/4.0/

\section{INTRODUCTION}

During the last few years, olive oil consumption has increased in several countries, mainly driven by the Mediterranean Diet, a dietary concept that provides important health benefits and has olive oil as one of its main components (Estruch, Lamuela-Raventós, \& Ros, 2020; Gavahian, Khaneghah, lorenzo, Munekata, Garcia-Mantrana, Collado \& Barba, 2019; Roselli, Carlucci, \& De Gennaro, 2016). According to data from Euromonitor International (2019), there was a growth in olive oil sales of $7.2 \%$ in 2019 in Brazil, totalling 678 million euros in sales, and of $2.5 \%$ in Portugal, totalling 178 million euros.

Companies that want to increase their participation in the olive oil market need to understand which attributes are most relevant to consumers in order to offer and communicate products that suit those preferences. Previous research has shown that acidity, price, origin, and brand are the most important attributes for Brazilians (Ambrosini, Specht, Blume, \& Lipp, 2017) and that Portuguese consumers place more importance on acidity, brand, price, color, and region of origin when choosing an olive oil (Rocha, Pereira, \& Carqueja, 2007). These studies, however, have some limitations: 1) 85\% of the sample in the first study resided in Rio Grande do Sul, which creates doubt as to whether the results would be the same if the participants were from other states, since the diversity in consumption habits among Brazilian states is high (Feil, Cyrne, Sindelar, Barden, \& Dalmoro, 2020; Hamza, Dalmarco, \& Pereira, 2018); 2) the second study was conducted more than 10 years ago, so there is room for many changes in consumer behavior from then to now; 3) Both studies did not compare the opinion of Brazilians and Portuguese to know which attributes are more important in each country. The high relevance of the olive oil markets in Brazil and Portugal calls for recent studies that review and complement the little knowledge we have about these consumers.

The present research aims to understand the purchase decision process of Brazilian and Portuguese consumers, comparing the attributes considered most relevant in each country. Two studies were conducted: in the first study of exploratory qualitative approach, interviews were conducted with consumers of olive oil in Brazil and Portugal to understand and identify the attributes 
that influence the purchase decision process. In the second study, a survey was conducted with 338 Brazilian and Portuguese consumers to compare the importance of the attributes in each country.

This article is organized as follows: first, a literature review is conducted on the attributes that impact the consumer purchasing decision process in general and olive oil in specific, then the methodological procedures and results of studies 1 (qualitative) and 2 (quantitative), respectively, are presented. Finally, the results of the studies are discussed, and the final considerations are presented.

\section{THE CONSUMER PURCHASING DECISION PROCESS}

The purchase decision process represents a map of the consumers' mind, which can be used by marketing professionals to compose their product mix, communication and sales strategies (Blackwell et al., 2005). Therefore, analyzing how consumers make their purchase decisions is essential (Koler \& Keller, 2012). This process is divided into five steps (Stankevich, 2017), presented in Figure 1.

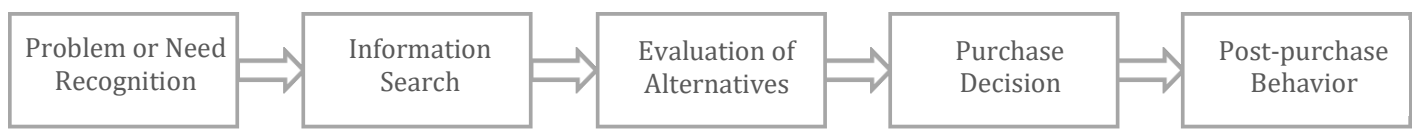

Figure 1. Model of the five stages of the consumer purchasing process

Source: Kotler and Keller (2012)

The purchasing decision process starts from the premise that a problem needs to be solved and that the solution can be found in the form of a product or service (Kotler \& Keller, 2012). Recognition of the problem occurs when the individual senses the difference between what they perceive to be the ideal (i.e., the desired state) versus their current state (i.e., the actual state) (Blackwell et al., 2005), i.e., when consumers realize they need something (Stankevich, 2017).

When recognizing the problem, the individual begins the search for information, seeking to fill the gap found between his ideal state and his current state (Stankevich, 2017). To do so, they may use the memories of their own experiences (internal search) or resort to other sources (external search), such as family, friends, advertisements, specialized magazines, etc. (Kotler \& Keller, 2012; Pinheiro, Castro, Silva \& Nunes, 2011). In low involvement purchases (e.g., when the consumer perceives low risk), there is usually little internal search and there may be no external search, but in high involvement purchases, decision making involves an intense internal and external search for information (Hawkins, Mothersbaugh, \& Best, 2007).

After seeking information, the consumer proceeds to the evaluation of alternatives (Stankevich, 2017). Much of the effort expended in a purchase decision is at this stage (Solomon, 2016) where the consumer uses criteria to compare the available options. These criteria depend on the degree of importance the consumer attaches to the attributes of a product (Cardoso, 2009). Product attributes can be intrinsic and extrinsic (Schiffman \& Kanuk, 2000). Intrinsic attributes are defined by physical and functional characteristics, such as color, taste and aroma. The extrinsic ones are related to the aspects and information involving the product, such as price, brand, packaging, labeling and country of origin, for example (Schiffman \& Kanuk, 2000). The criteria used by consumers vary according to the product, the set of alternatives considered, the individual's own characteristics, the relationship with the product and the situations of purchase and consumption (Blackwell et al., 2005).

The next stage is the purchase decision, a stage in which the consumer creates preferences for a certain option or options and makes a set of decisions: decision for brand; decision about the supplier; decision for quantity; decision for occasion and decision for payment method (Kotler \& Keller, 2012; Solomon, 2016; Stankevich, 2017).

The fifth and final stage is the post-purchase behavior, in which the customer experiences a sense of satisfaction or dissatisfaction (Stankevich, 2017). If the experience of using the product is 
higher or equal to what was expected, he will feel satisfied, and if it does not meet expectations, he will be dissatisfied (Engel, Blackwell, \& Miniard, 2000; Solomon, 2016).

\section{PRODUCT ATTRIBUTES THAT INFLUENCE THE PURCHASE DECISION}

As seen in the evaluation of alternatives stage, consumers consider some intrinsic and extrinsic product attributes in the purchase decision process (Schiffman \& Kanuk, 2000). Thus, based on studies already conducted (e.g., Ambrosini et al., 2017; Cicerale, Liem \& Keast, 2016; Herz, 2013; Panico, Giudice, \& Caracciolo, 2014; Rocha et al., 2007, among others), the attributes usually researched in the food literature in general and, specifically, for olive oils will be presented.

\section{Country of origin}

Country of origin is one of the most studied subjects in the literature related to international marketing and food consumption (Herz, 2013; Thøgersen, Pedersen, Paternoga, Schwendel, \& Aschemann-Witzel, 2017). In the case of olive oils, studies conducted in Brazil, Portugal, and Italy show that country of origin is an attribute valued by consumers (Ambrosini et al., 2017; Panico et al., 2014; Rocha et al., 2007).

\section{Price}

In situations of low product differentiation and when there is a consumer budget constraint, price has a significant importance in the purchase decision process (Santos \& Botelho, 2009). In the case of olive oils, price has been considered as a quality signal and an attribute that influences the decision process (Ambrosini et al., 2017; Cicerale et al., 2016; Rocha et al., 2007).

\section{Brand}

Studies show that consumers choose products not only based on price or functionality, but also, based on their evaluation of the brands (Pimentel, 2007). In the case of olive oils, the higher the brand value of the product, the better the consumer attitude and the higher the consumption (Ordonez, Entrena, Cabrera, \& Henselerd, 2018). Brand has also been identified as an important attribute in other olive oil studies (Ambrosini et al., 2017; Rocha et al., 2007).

\section{Package}

In general, the packaging of a product can make it visually more appealing and versatile, influencing the consumer's purchase decision (Newton, 2000). In the specific case of olive oils, studies show that packaging influences consumer perception and purchase decision (Cicerale et al., 2016; Roselli et al., 2016).

\section{Label}

The information contained in food labels, such as product origin, nutritional qualities, ingredients used, and the manufacturing process has been observed as a factor influencing quality and taste perceptions, and the choice of olive oils (Cicerale et al., 2016; Panico et al., 2014).

\section{Acidity level}

In the specific case of olive oil, the acidity level appears as a relevant attribute in the purchase decision of Brazilians and Portuguese (Ambrosini et al., 2017; Rocha et al., 2007), but this attribute was not highlighted as relevant in most of the studies reviewed (Cicerale et al., 2016; Ordonez et al., 2018; Panico et al., 2014). Studies 1 and 2 will investigate whether the acidity level and the other attributes highlighted in the previous paragraphs are relevant for Brazilians and Portuguese in the olive oil purchasing decision process. 


\section{STUDY 1}

In this first study, we intended to identify which attributes are considered most important by consumers in their decision to purchase olive oils. The main objective was to understand the purchase decision process and analyze whether other attributes, besides those identified in the literature review, would be relevant in this process. As there is no rule for defining the number of participants in qualitative exploratory approaches (Malhotra, 2006), semi-structured individual interviews were conducted with five Brazilian consumers and five Portuguese consumers, selected by convenience. At the end of these interviews, the collected material was analyzed and deemed sufficient for an initial understanding of the olive oil purchasing decision process.

\section{Methodological procedures}

Each interview was conducted by using an interview guide prepared for this purpose, which contained pre-defined questions, which were asked through an informal and flexible conversation, allowing each interviewee to bring up what they thought was most relevant, in order to avoid the influence of the researcher (Lincoln \& Guba, 1985). For a better understanding of what was said by the olive oil consumers, the interviews were recorded and then transcribed, aiming not to lose the essence of the answers.

The five stages model of the purchase decision by Kotler and Keller (2012) served as a guide for the preparation of the interview guide. However, only the first three stages of this model were addressed in the guide (problem recognition, information search and evaluation of alternatives), because they are the stages that influence the purchase decision. In addition, the attributes highlighted in the literature review (country of origin, price, brand, packaging and label), were also addressed in the interview guide, with all questions adapted from the study of Tagnin and Giraldi (2013).

Before the ten interviews that are part of this study, two interviews were conducted to test the guide: one with a Brazilian olive oil consumer and another with a Portuguese consumer, in order to understand if the approach proposed in the guide was appropriate and easy to understand. After the tests, some changes were made, such as the removal of a question considered repetitive by the interviewees and the inclusion of a new question referring to the preference regarding the type of olive oil and its purpose of use, since this information was mentioned by both interviewees.

After transcribing the ten interviews, the contents were coded and grouped into four categories based on Kotler and Keller's (2012) purchase decision model: problem recognition, information search, evaluation of alternatives, and a complementary category reserved for additional information from the interviewees, with suggestions that may be useful to marketing professionals and companies in the industry.

\section{Results and Discussion}

All the 10 interviewees were regular buyers and consumers of olive oil, aged between 29 and 67, with higher education, residing in the states of Pernambuco and Ceará (Brazil) and in the district of Lisbon (Portugal). Most of the interviewees were women.

In the first category, "problem recognition," which marks the beginning of the purchase decision process, we tried to understand the motivations and reasons why consumers want to buy and consume the product. Both the Brazilian and Portuguese respondents said they use olive oil regularly in their daily lives, with practically everything: in soup, on bread, for cooking, frying, seasoning salads or finishing dishes. Most of the interviewees said they always have olive oil at home and consider it a regular item on their shopping list: "I cook almost everything with olive oil. I never lack olive oil in my house. If the bottle is half empty, I buy another one. Or, if there is some olive oil on sale, I take the opportunity and buy it because I know it won't spoil" (Filipa, Portuguese). All interviewees agreed that the main reason for buying olive oil is its taste and the fact that it is a healthier fat, "which is good for your health" (Wilma, Brazilian). One Brazilian and one Portuguese mentioned the family influence on olive oil consumption, as a food habit that accompanies them since childhood. This converges with what Blackwell et al. (2005) and Kotler and Keller (2012) say about social factors (and especially family) influencing our preferences and consumption habits. 
In the second category, "information search," we analyzed which are the information sources used and the information content usually sought by consumers to help them in the purchase decision. Most of the Brazilians interviewed, said they use the label and rely on this source to help them in the purchase decision while most of the Portuguese interviewees said they do not search for information about olive oil because they are used to buying certain brands or products of their choice. At this stage, we could notice a greater need for information coming from Brazilians, mainly because in Brazil there are occurrences of olive oils mixed with oils and sold in the market as pure, extra virgin olive oils (Olive Oil Times, 2017). Therefore, in addition to checking information on labels, some consumers also said they occasionally use the Internet to check reliable information sources in order to find out which brands are more reliable. Information search may also occur through conversations with doctors or nutritionists. So there seems to be a greater external information search (doctors, nutritionists and the Internet) among Brazilian respondents.

When asked what information they usually look for on olive oil, the Brazilians interviewed, who usually read the labels, cited the acidity level and the extra virgin type of olive oil as the most sought after information. The country of origin was also mentioned by some, but when the brand is already known, they say it is not necessary to see all this information. Most of the Portuguese interviewed, who had said they don't look for information, justified that when they do, it is usually to verify the acidity level. This converges with what Blackwell et al. (2005) say about the passive posture in the information search when consumers already have a preference for a particular product or brand.

In the third category, "evaluation of alternatives", the central stage of this study, which corresponds to the evaluation criteria used by each individual to choose the product, we tried to identify the most relevant attributes for the olive oil purchase decision in each country. The majority of Brazilians agreed that low acidity level was the most important characteristic for the purchase decision, with the acidity level being incorrectly associated with better taste by the interviewees. However, the acidity level contained on labels is a marker of the purity of olive oil and refers to its chemical and nutritional properties, and is imperceptible to the palate (Casa do Azeite, 2019a). The extra virgin appeared as the most remembered type of olive oil option. Price was also mentioned by some Brazilian consumers, but always in a quality-price comparison for known and trusted brands. These results diverge in part from the study conducted by Ambrosini et al. (2017) with Brazilians in southern Brazil, which indicated acidity level, price, origin, and brand as the most used criteria for the purchase decision. Thus, in the interviews conducted, the acidity level also stands out, but accompanied by the type of olive oil (extra virgin), which according to the Brazilians interviewed is one of the most relevant and sought after characteristics at the time of purchase. Unlike the study by Ambrosini et al. (2017), origin did not appear as a relevant characteristic, at least in this first moment in which respondents were asked to spontaneously mention the most important attributes for them (without suggestions from the interviewer).

Most of the Portuguese made the same association as the Brazilians of the acidity level as an indicator of quality and better taste. The brand was mentioned with the same relevance by these consumers. The price appeared, but with less importance for some of the Portuguese, who said they use it only as a guide to purchase between brands of their preference. These attributes were mentioned in the same order of importance in the study by Rocha et al. (2007), which suggests that the Portuguese criteria for choosing olive oil have not changed much in recent years.

Also, within the analysis of the most important attributes, a Brazilian and a Portuguese consumer argued very similarly the importance of the color of olive oil for the purchase decision. These interviewees associate the color of the olive oil with the quality of the product. This same perception was presented in the study by Cicerale et al. (2016) on olive oil consumer behavior in the UK. However, this is an incorrect perception of consumers, given that color is not directly linked to the quality or taste of olive oil, indicating only the shade of the harvested olives (Casa do Azeite, 2019a).

Packaging was also mentioned by consumers of both nationalities as an attribute they observe at the time of purchase, but compared to the other characteristics, it was less relevant. One Brazilian said that sometimes the packaging can convince him to pay more for the product if it can convey a good impression. 
Thus, continuing the mapping of the criteria used for choosing the product, consumers were asked about their preferences regarding the types of olive oil and their respective purposes of use. The majority of Brazilian respondents showed their preference for extra virgin olive oil, because it has lower acidity and better taste, claiming to have a single bottle at home that is used for everything: cooking, seasoning, finishing dishes, etc. They also use this oil for frying, but in smaller quantities, because some of them said they also use soybean or sunflower oil for this type of preparation. This result converges with the results found by Ambrosini et al. (2017) on the preference of Brazilians for extra virgin olive oil and the presence of soybean oil in the diet of this population. Most of the Portuguese interviewees, on the other hand, did not make much distinction between virgin and extra virgin olive oil: "I don't have a specific olive oil. I can buy virgin or extra virgin, I like to vary" (Ana, Portuguese). The majority said they use "the same olive oil for everything" (Filipa, Portuguese). This again converges with the results presented by Rocha et al. (2007), which showed the Portuguese lack of knowledge about the concept of each olive oil and the fact that most use the same olive oil for different culinary uses.

When asked about how price influences the decision to buy olive oil, some Brazilians and Portuguese stated that they are willing to pay more for the product when they consider the olive oil of better quality. In general, price is not the main attribute evaluated and, for some of the interviewees, not even a limiting factor for the purchase. This result contradicts the results of Ambrosini et al., (2017) and Rocha et al. (2007) who state that price is one of the most important attributes for Brazilians and Portuguese.

Next, respondents were asked about the influence of the country of origin of the olive oil on their purchasing decision. The Brazilian respondents said they care about the country of origin of the olive oil, although they do not consider this factor the most relevant for the purchase. Portugal appeared in prominence in the preference of Brazilians: "I prioritize the Portuguese olive oils for a matter of tradition and trust. I will always give preference to them" (Sérgio, Brazilian). Countries like Spain and Greece were also mentioned. All the Portuguese interviewees advocated the consumption of Portuguese olive oil and stated that they value the origin when buying, mainly because they like the taste of the product and recognize that Portugal produces good olive oils. This valuation of national olive oils in Portugal, a country that produces and exports a large quantity of olive oil, is in line with the analysis done by Panico et al., (2014). The authors saw that consumers residing in an olive oil producing country prefer local olive oils.

When asked about the influence of the brand in the purchase decision, a good part of the Brazilians interviewed said they are open to experimentation: "I don't have a favorite brand. I can spend some time consuming a brand I already know and, if by chance another one comes up, I am willing to try it to get to know it. I usually buy the same brand when I am short of time to choose" (Tatiana, Brazilian); "Since I was born, the olive oil in my house was Gallo. But nowadays I am demystifying this to get to know new olive oils. Gallo is very strong in my memory, but I only buy when there is a great offer, I am not loyal to brands. I like to experiment" (Isadora, Brazilian). One can notice, therefore, the strength of Gallo in the country and the presence of other brands, both Portuguese and Spanish, such as Vila Flor, Andorinha, Esporão, Borges and EA. For the Portuguese interviewees, the brand has a more relevant role than for Brazilians: "It (the brand) influences a lot" (Catarina, Portuguese); "It's important and I usually go for the same brand" (Ana, Portuguese); "Very relevant. The brands I consume today are brands from my childhood" (Filipa, Portuguese). These results converge with what Ordonez et al. (2018) say about the importance of brand credibility in the choice of olive oils. For the Portuguese respondents, the most cited brands were Gallo and Oliveira da Serra, followed by Esporão. The latter, was referenced as a premium category olive oil brand, usually purchased on promotion.

Then, consumers were asked about the influence of the label on the purchase decision. This attribute, already mentioned in the interviews as a source of information, was analyzed in more detail in order to understand its potential to influence the purchase. Most of the Brazilians interviewed stated that the label contains relevant information to help them make a purchase decision. Thus, for them, in addition to informing, the label has the role of drawing attention at the store: "It helps me a lot and influences my purchase, especially the back side, which has the physical and chemical 
characteristics of the product. I've already stopped buying because I didn't know if it fit the characteristics I was looking for" (Wilma, Brazilian). This result reinforces what was found by Panico et al. (2014) about the importance of clarity in labeling, due to the fact that many consumers use its information to minimize the risks of purchase, especially when they are not familiar with the product. Some Portuguese respondents stated that the label is a minor factor, as they usually go straight to the brands they usually buy. Others said they use it because the information it contains helps them in choosing the olive oil. Despite the diverging opinions among the Portuguese, it was possible to observe a lower influence of this attribute compared to its influence for Brazilians.

When asked about the influence of packaging on the purchase decision, the answers from Brazilian and Portuguese respondents were balanced. Some agreed that package shape, size (dimension), functional and visual aspect influence, drawing attention at the moment of purchase, while others did not care so much about this attribute, believing that there are more relevant characteristics to be considered. The only criterion that was transversal to all the interviewees was the preference for glass packaging. This result converges with the findings of Cicerale et al. (2016), where most consumers analyzed in their study, associated plastic packaging with cheaper cooking oils.

Finally, in the fourth category, "extra information," we tried to gather the interviewees' opinions that could be useful to the olive oil sector in each country. Some similar suggestions were made by Brazilians and Portuguese, since both agreed that there is a need to know more about the characteristics and differences between olive oils: "I would like to have more information about the differences between the labels offered in the market (...), because I don't know how to distinguish what they are and what the purpose of each one is. If I understood better, I could even pay more for the product" (Patrícia, Portuguese); "Companies should teach consumers better about the characteristics of olive oil. It can be through television, because I would hardly follow an olive oil brand on Instagram. Besides, they can make information available in booklets, on the shelves or in tasting actions with promoters" (Amanda, Brazilian). In the study by Ambrosini et al. (2017), educational actions had already been suggested as a way to stimulate olive oil consumption in Brazil.

\section{STUDY 2}

This second study complements the first one, statistically testing the relevance of the attributes investigated in the qualitative study and comparing the results between Brazilian and Portuguese. In addition to the attributes that had been identified in the literature review (country of origin, price, brand, packaging, label and acidity level), attributes that emerged from the results of study 1 (type of olive oil, color and taste) were also measured. A survey was conducted with a total of 338 participants, of which 206 were Brazilians living in Brazil and 132 were Portuguese living in Portugal. It was decided not to collect data from Brazilians and Portuguese residing in other countries due to restrictions or differences in consumption options in each country, which could influence the consumers' purchasing process.

\section{Methodological procedures}

The questionnaire was developed using the Qualtrics platform and distributed by e-mail and social networks. Before being distributed, the questionnaire was tested with two marketing specialists (one Brazilian and one Portuguese) in order to check the clarity of the questions and the suitability of the language due to the grammatical differences between the two countries. After this validation, some changes were made based on the experts' suggestions.

To ensure that only olive oil consumers would respond to the survey, two filter questions were inserted at the beginning of the questionnaire. In the questionnaire, participants were asked to think about the olive oil they usually buy to answer the questions about the attributes identified in the literature and in the qualitative study. Thus, purchase intention or decision was not measured, since all the answers were already related to the olive oil that the participants usually buy.

To measure the degree of importance of each attribute, Gracia and de Magistris' (2008) scale was adapted for the context of this research, where $1=$ not at all important and $5=$ very important. Although this scale already measures the relevance of all nine attributes being analyzed in this study, a 
few extra questions were added to investigate in more detail some of the attributes. In the case of country of origin, based on da Silva, Lazzari, Milan, and Eberle (2015), participants were asked to answer whether they have a preference for the origin of some country (yes/no) and if so, which country it would be. Regarding price, the scale of Shoham, Kahle, and Rose (1995) was used, with the question "When you decide to buy olive oil, do you usually buy it", followed by three semantic differential items, such as $0=$ lower price, even if it is not as good and $10=$ higher quality, even if it costs more $(\alpha=0.90)$. In the case of brand, olive oil brand loyalty was measured with two items used by Reis (2010) and Yoo and Donthu (2001), such as "I consider myself loyal to the olive oil brand I usually buy", where $1=$ strongly disagree and $5=$ strongly agree $(r=0.68)$. The attractiveness and quality of the packaging was also measured in two separate items based on Yan, Sengupta, and Wyer (2014): "The packaging of the olive oil you usually buy is $1=$ Unattractive and 7=Very attractive, 1=Low quality; 7=Very high quality." Finally, regarding the label, two questions were asked based on Kumar and Kapoor's (2017) study: "Do you read the label of the olive oil before purchase?"; "Does the label of the olive oil influence your purchase decision?" (1=Never; $5=$ Always).

\section{Results and discussion}

Regarding the sample of this study, $72 \%$ of the Brazilian participants and $64 \%$ of the Portuguese participants were women. The average age of the Brazilians was 45 years, and of the Portuguese was 42 years. As for the level of education, $93 \%$ of the Brazilians and $74 \%$ of the Portuguese had completed higher education. Of the Brazilian participants, most lived in Pernambuco (55\%), and the others were from other Brazilian states (Rio de Janeiro, São Paulo, Rio Grande do Sul, Santa Catarina, Paraná, Goiás, Minas Gerais, Bahia, Alagoas, Paraíba, Ceará, Rio Grande do Norte, and Pará). Most of the Portuguese lived in the district of Lisbon (86\%), while others lived in other districts of Portugal (Braga, Évora, Leiria, Porto, Santarém and Setúbal).

Regarding the consumption habits of the sample, it was observed a strong presence of olive oil in the diet of the participants, since $57 \%$ of the Brazilians and $56 \%$ of the Portuguese said they consume the product "always", and $32 \%$ of the Brazilians and $37 \%$ of the Portuguese said they consume "often". As for the type of olive oil consumed, $88 \%$ of Brazilians usually buy "extra virgin olive oil", showing a strong preference for this type of olive oil as had already been identified in study 1 and in the study by Ambrosini et al. (2017). In the case of the Portuguese, 55\% said they buy "extra virgin olive oil", 36\% "virgin olive oil."

As for the most relevant attributes for the purchase decision, the highest averages among Brazilians (denoting greater relevance of the attribute) were, respectively: taste $(M=4.65)$, type of olive oil $(M=4.64)$, brand $(M=4.06)$, acidity level $(M=4.03)$ and price $(M=3.95)$. For the Portuguese, the most relevant attributes were the taste $(M=4.51)$, the type of olive oil $(M=4.38)$, the country of origin $(M=4.25)$, the acidity level $(M=3.94)$ and the price $(M=3.80)$.

The first difference that can be perceived between the Brazilians and the Portuguese regarding the most relevant attributes is the brand, which appears for the Brazilians, but does not appear for the Portuguese. When performing a t-test to compare the means of brand importance for the participants of both nationalities, it turns out that in fact the brand is more relevant for the Brazilians $(M=4.06)$ than for the Portuguese $(\mathrm{M}=3.55, \mathrm{t}(336)=-4.19, \mathrm{p}<0.001)$. Despite the importance of the brand for Brazilians, they did not show much brand loyalty in another question, where the mean for Brazilians and Portuguese was the same $(\mathrm{M}=3.50)$ and very close to the midpoint of the scale $(3.00)$ used to measure loyalty. When considering the results of studies 1 and 2 on brand, there is a tendency for the brand of olive oil one usually buys to be the first choice, but it does not mean that there will be brand loyalty at the time of purchase, as many of the Brazilians and the Portuguese reported in study 1 having a preference for more than one brand and being open to trying other brands - trusted brands, in the case of Brazilians, because there are problems of adulteration of olive oils in this market (Olive Oil Times, 2017).

The second difference between Brazilians and Portuguese regarding the five most relevant attributes concerns the country of origin, which appears for Portuguese, but does not appear for Brazilians. The t-test shows that country of origin is significantly less relevant for Brazilians $(\mathrm{M}=3.50)$ 
than for the Portuguese $(M=4.25, t(336)=5.20, p<0.001)$. This result is consistent with the result of another question that asked if the participants had a preference for the origin of some country, where more Portuguese (87\%) than Brazilians (60\%) answered yes. Among the respondents who said yes, $97 \%$ of the Portuguese and $72 \%$ of the Brazilians indicated Portugal as their preferred country of origin. Spain (12\%), Italy (10\%), and Greece (3\%) appear in second, third, and fourth place, respectively, for Brazilians who indicated a preference for some country of origin. This preference of Brazilians for Portuguese olive oil was also identified by Ambrosini et al. (2017), but unlike what was found by the authors, in the present study Brazilian olive oils are not part of the consumers' preference, as only one Brazilian participant made reference to national olive oil. It is believed that this difference arose because the investigation of Ambrosini et al. (2017) was conducted only in southern Brazil, therefore, a region more advanced in the production of olive oils, which may have influenced consumers' preference for Brazilian origin. Overall, the results on country of origin found in study 2 are similar to the results found in study 1 .

Table 1 shows the mean values of importance for each attribute and for each nationality and the $\mathrm{p}$ value that indicates whether the differences between the mean values for Brazilians and Portuguese are statistically different. In this table, we can see that some attributes were statistically more relevant for Brazilians than for the Portuguese (i.e., brand, packaging, label and type of olive oil; $\mathrm{p}<0.01$ ). The results related to brand have already been discussed in a previous paragraph of this section, as well as the types of olive oil most used by the sample. For the case of packaging and label, there were extra questions to better understand the influence of these attributes on the purchase decision of Brazilians and Portuguese. Brazilians $(M=5.40)$ rated the attractiveness $(M=5.11, t(336)=-$ $3.61, \mathrm{p}<0.001)$ and quality $(\mathrm{M}=5.69, \mathrm{t}(336)=-3.03, \mathrm{p}<0.01)$ of the packaging of the olive oil they usually buy as superior to the Portuguese (Mattr=4.60, Mqual=5.27) (measured on a seven-point scale). The results about the packaging corroborate the results presented by Rocha et al. (2007), in which the packaging was considered a characteristic of less importance to the Portuguese. As for the label, the Brazilians $(M=4.06)$ reported reading the label more than the Portuguese $(M=3.78, t(336)=-2.02$, $\mathrm{p}<0.05)$. Brazilians $(\mathrm{M}=3.72)$ also reported being more influenced by the label at the time of purchase than the Portuguese $(M=3.30, t(336)=-2.98, p<0.01)$. According to Roselli et al. (2016), one reads the label more when there is little familiarity with the product, and this may be an explanation for why Brazilians read and are more influenced by the label than the Portuguese.

Table 1 also shows that only one of the attributes was more relevant for the Portuguese than for the Brazilians (i.e., country of origin; $\mathrm{p}<0.001$ ) and that for some attributes there was no statistical difference between the averages of Brazilians and Portuguese (i.e., price, acidity, color, and taste; $\mathrm{p}>0.05$ ). The results regarding the country of origin have already been discussed in a previous paragraph of this section. In the case of price, there was an extra scale to measure the influence of this attribute on the purchase decision and, also, there was no difference between Brazilians and Portuguese ( $p>0.05)$.

Table 1

Importance of attributes when buying olive oil

\begin{tabular}{l|l|c|c}
\multicolumn{2}{c|}{} & Mean $^{1}$ & p \\
\hline \multirow{2}{*}{$\begin{array}{l}\text { Country of } \\
\text { origin }\end{array}$} & Portuguese & 4.25 & \multirow{2}{*}{0.000} \\
\cline { 2 - 3 } & Brazilians & 3.50 & \\
\hline \multirow{2}{*}{ Price } & Portuguese & 3.80 & \multirow{2}{*}{0.132} \\
\cline { 2 - 3 } & Brazilians & 3.95 & \\
\hline \multirow{2}{*}{ Brand } & Portuguese & 3.55 & \multirow{2}{*}{0.000} \\
\cline { 2 - 3 } & Brazilians & 4.06 & \\
\hline \multirow{2}{*}{ Packaging } & Portuguese & 2.80 & \multirow{2}{*}{0.000} \\
\cline { 2 - 3 } & Brazilians & 3.42 & \\
\hline
\end{tabular}




\begin{tabular}{l|l|c|c}
\hline \multirow{2}{*}{ Label } & Portuguese & 2.67 & \multirow{2}{*}{0.000} \\
\cline { 2 - 3 } $\begin{array}{l}\text { Type of olive } \\
\text { oil }\end{array}$ & Brazilians & 3.34 & \\
\hline \multirow{3}{*}{ Acidity level } & Portuguese & 4.38 & \multirow{2}{*}{0.001} \\
\cline { 2 - 3 } & Brazilians & 4.64 & \\
\hline \multirow{2}{*}{ Color } & Portuguese & 3.94 & \multirow{2}{*}{0.527} \\
\cline { 2 - 3 } & Brazilians & 4.03 & \\
\hline \multirow{3}{*}{ Taste } & Portuguese & 3.30 & \multirow{2}{*}{0.174} \\
\cline { 2 - 3 } & Brazilians & 3.49 & \\
\hline & Portuguese & 4.51 & \multirow{2}{*}{0.114} \\
\cline { 2 - 3 } & Brazilians & 4.65 & \\
\hline
\end{tabular}

Note $^{1}: 1$ = Not at all important; 5 = Very important

\section{FINAL CONSIDERATIONS}

The objective of this research was to identify and compare the most relevant attributes for consumers in their decision to purchase olive oil in Brazil and Portugal. Based on the studies carried out, we can say that the most relevant attributes for the sample of Brazilians were the taste, the type of olive oil, the brand, the acidity level and price, in that order. For the Portuguese, the most relevant attributes were the taste, the type of olive oil, the country of origin, the acidity level and the price, respectively. We also identified that some attributes are more important to Brazilians than to the Portuguese participants: brand, packaging, label and type of olive oil. However, the country of origin is more important to the Portuguese than to the Brazilian participants.

In terms of the contribution of this study to the advance of knowledge from previous studies conducted with Brazilians (Ambrosini et al., 2017) or Portuguese (Rocha et al., 2007), some results were different, which suggests a difference in consumer behavior. This difference may be a result of the fact that the samples of this study and the study of Ambrosini et al. (2017) are from different regions of Brazil and also the fact that the study of Rocha et al. (2007) occurred more than 10 years ago, so consumer behavior may have changed in this period of time. Regarding the Brazilians, the main differences identified were the fact that the country of origin did not appear as one of the most relevant attributes as it did in the study by Ambrosini et al. (2017) and the fact that the type of olive oil appeared as a relevant attribute, which was not the case in the study by Ambrosini et al. (2017). As for the Portuguese, the main differences were that brand and color, identified as part of the most relevant attributes in the study by Rocha et al. (2007), were not among the five most relevant attributes for the Portuguese investigated in study 2, but the type of olive oil was, unlike what happened in the study by Rocha et al. (2007).

Results from both studies that were conducted allow us to make some recommendations for companies that wish to sell olive oil in Brazil and Portugal:

1) Packaging and labeling: although packaging and labeling are not among the most relevant attributes for Brazilians, they are of greater importance to Brazilians than to the Portuguese. Therefore, companies that want to sell olive oil in Brazil need to pay more attention to these two attributes than companies that intend to sell olive oil in Portugal, mainly because Brazilians reported buying more attractive and higher quality packaging and showed more use of the label to look for information about the products. The label could contain explanations of what the acidity level means and suggestions for use for each type of olive oil - the acidity level and the type of olive oil are further discussed in points 2 and 3 of this list;

2) Acidity level: a lack of knowledge by Brazilians and Portuguese was observed regarding the acidity level, mistakenly associated with the taste of olive oil (Ambrosini et al., 2017; Casa do Azeite, 2019a). Since this attribute is highly relevant for Brazilians and Portuguese, companies that intend to 
sell in both markets need to demystify this false perception, especially if the acidity level of their products is in the range considered "bad" by consumers. For such demystification, one can use the label (especially for Brazilians) and other forms of communication (e.g., tasting in supermarkets) that explain this characteristic.

3) Type of olive oil: In the case of companies that intend to sell in the Portuguese market, it is suggested to prioritize the virgin and extra virgin olive oils, which are the favorite types by the sample investigated. However, for companies that wish to sell in the Brazilian market, it is suggested to prioritize the extra virgin type, which was the great favorite of the sample investigated. For companies that wish to sell other types of olive oil than those suggested above, the ideal is to try to educate the consumer through the product label (especially in the case of Brazilians) for which occasion that type of olive oil is indicated. For example, highlight on the label a message such as "Ideal for sauteing and roasting". Extravirgin olive oil is ideal for raw consumption, virgin olive oil is ideal for cooking, baking and sauteing, but can also be used for raw consumption, while olive oil that is neither virgin nor extravirgin is ideal for frying and cooking (Casa do Azeite, 2019b). If consumers understood more clearly what differs one olive oil from another, they would likely not limit themselves to buying just one olive oil, increasing consumption of this product;

4) Country of origin and brand: Whether due to market protection or consumer preference reasons, it is suggested that foreign companies do not attempt to sell their olive oils in Portugal. For companies wishing to sell olive oil in Brazil, despite the preference for Portuguese olive oils, it is known that Brazilians are open to olive oils of other nationalities. Therefore, Portuguese companies that want to protect their space in this market should strengthen their brand through the use of symbols (e.g., rooster, flag, tradition through time of existence), label colors (e.g., green and red) and images suggestive of consumption (e.g., codfish) that refer to Portugal, so that the quality of that country is associated with olive oil and stands out among the other labels. The other foreign companies that sell olive oil in the country can explore other attributes cited as relevant in this research (e.g. taste, type of olive oil, brand, label and packaging) in order to become more attractive at the stores and create differentiation;

5) Since taste is the most important attribute for both Brazilians and Portuguese, it is recommended to conduct tastings in stores and supermarkets, because through sensory analysis consumers will be able to correctly evaluate each product and choose the olive oil based on their personal preference (Dunkovic, 2016). Since supermarkets are considered places of great potential for people's nutritional education (Scott, Begley, Miller, \& Binns, 1991), it is also possible to use these tastings as a way to clarify doubts and educate the consumer about the myth of the relationship between acidity and taste, as well as demystify existing beliefs also about color, which is often mistakenly used as a quality benchmark.

The main limitation of this work was the use of convenience samples in Brazil and Portugal, which does not guarantee representative samples of the populations of these countries in terms of education, region of residence, etc. The convenience sample brings interesting insights about a portion of the population, but does not allow for an accurate picture of what happens in different social strata, geographic regions, etc. (Etikan, Musa, \& Alkassim, 2016). Although this is a common limitation of other studies (e.g., Ambrosini et al., 2017; Ordonez et al., 2018; Rocha et al., 2007), it would be interesting if future studies complement this research with secondary data (e.g., sales reports) that allow cross-referencing between the attributes of the best-selling products and the sociodemographic characteristics of consumers.

\section{References}

Ambrosini, L. B., Specht, S., Blume, R. \& João, P. L. (2017). Comportamento de compra dos consumidores de azeite de oliva no Brasil: um estudo exploratório. Anais do Congresso da Sociedade Brasileira de Economia, Administração e Sociologia Rural, Santa Maria, RS, Brasil. 
Blackwell, R. D., Miniard, P. W. \& Engel, J. F. (2005). Comportamento do Consumidor. 9. ed. São Paulo: Thomson.

Cardoso, A. A. (2009). O Comportamento do Consumidor: por que é que os consumidores compram? 1.ed. Lisboa: Lidel.

Casa do Azeite (2019a). Curiosidades. Recuperado de: http://www.casadoazeite.pt/Azeite/Curiosidades

Casa do Azeite (2019b). Como escolher. Recuperado de: http://www.casadoazeite.pt/Azeite/Comoescolher

Cicerale, S., Liem, G., \& Keast, R.S.J. (2016). Consumer perception, attitudes, liking and preferences for olive oil. In Boskou, Dimitrios and Clodoveo, Maria Lisa (eds), Products from olive tree, InTech, Rijeka, Croatia, 157-171.

da Silva, S. M., Lazzari, F., Milan, G. S., \& Eberle, L. (2015). 0 efeito país de origem e o comportamento do consumidor em relação a vinhos. REAd-Revista Eletrônica de Administração, 21(1), 89-112.

Dunkovic, D. (2016). The effectiveness of offering food samples to increase purchase in supermarket settings. The Business \& Management Review, 8(1), 54.

Engel, J. F., Blackwell, R. D. \& Miniard, P. W. (2000). Comportamento do Consumidor. 8. ed. Rio de Janeiro: LTC.

Estruch, R., Lamuela-Raventós, R. M., \& Ros, E. (2020). The bitter taste of extra virgin olive oil for a sweet long life. Journal of the American College of Cardiology, 75(15), 1740-1742.

Etikan, I., Musa, S. A., \& Alkassim, R. S. (2016). Comparison of convenience sampling and purposive sampling. American Journal of Theoretical and Applied Statistics, 5(1), 1-4.

Euromonitor International (2019). Edible Oils in Portugal / Brazil, Country Report. Recuperado de: https://www.portal.euromonitor.com/portal/Analysis/Tab

Feil, A. A., Cyrne, C. C. S., Sindelar, F. C. W., Barden, J. E., \& Dalmoro, M. (2020). Profiles of sustainable food consumption: Consumer behavior toward organic food in southern region of Brazil. Journal of Cleaner Production, 258 (120690).

Gavahian, M., Khaneghah, A. M., Lorenzo, J. M., Munekata, P. E., Garcia-Mantrana, I., Collado, M. C., ... \& Barba, F. J. (2019). Health benefits of olive oil and its components: Impacts on gut microbiota antioxidant activities, and prevention of noncommunicable diseases. Trends in food science \& technology, 88, 220-227.

Gracia, A., \& de Magistris, T. (2008). The demand for organic foods in the South of Italy: A discrete choice model. Food policy, 33(5), 386-396.

Hamza, K. M., Dalmarco, D. D. A. S., \& Pereira, F. A. D. M. (2018). Sustainable consumption profile differences among Brazilian regions. Journal of Environmental Planning and Management, 61(9), 1553-1569.

Hawkins, D. I., Mothersbaugh, D. L. \& Best, R. J. (2007). Comportamento do Consumidor: construindo a estratégia de marketing. 10. ed. Rio de Janeiro: Elsevier.

Herz M. (2013) The country-of-origin concept reassessed - The long path from the 'made-in' label. In: Baumgarth C., Boltz DM. (eds) Impulse für die Markenpraxis und Markenforschung. Springer Gabler, Wiesbaden.

Kotler P. \& Keller K.L. (2012). Marketing Management, 14th ed. Upper Saddle River: Prentice Hall.

Kumar, N. \& Kapoor, S. (2017). Do labels influence purchase decisions of food products? Study of young consumers of an emerging market. British Food Journal, 119(2), 218-229.

Lincoln, Y. S. \& Guba, E. G. (1985). Naturalistic Inquiry. London: Sage Publications.

Malhotra, N. (2006). Pesquisa de Marketing: uma orientação aplicada. Porto Alegre: Bookman.

Olive Oil Times (2017). Brasil revela fraude generalizada no azeite. Recuperado de: https://www.oliveoiltimes.com/pt/business/brazil-reveals-widespread-olive-oilfraud/56395

Ordonez, M. S., Entrena, M. R., Cabrera, E. R., \& Henseler, J. (2018). Understanding product differentiation failures in agri-food markets: The role of product knowledge and brand credence in olive oil markets. Food quality and preference, 68, 146-155. 
Panico, T., Del Giudice, T., \& Caracciolo, F. (2014). Quality dimensions and consumer preferences: A choice experiment in the Italian extra-virgin olive oil market. Agricultural Economics Review, 15(2), 100-112.

Pinheiro, R. M, Castro, G. C., Silva, H.H. \& Nunes, J. M. G. (2011). Comportamento do Consumidor. 1. ed. Rio de Janeiro: FGV.

Rocha, J., Pereira, F. \& Carqueja, L. (2007). Hábitos de consumo e conhecimento dos consumidores sobre o azeite. Anais do Congresso de Estudos Rurais. Estoril, Portugal.

Roselli, L., Carlucci, D., \& De Gennaro, B. C. (2016). What Is the Value of Extrinsic Olive Oil Cues in Emerging Markets? Empirical Evidence from the US E-Commerce Retail Market. Agribusiness, $32(3), 329-342$.

Reis, E. G. (2010). O valor da marca a partir do conceito de brand equity baseado no consumidor: mensuração através da escala multidimensional em ocasiões de compra e consumo simultâneo e não-simultâneo de um produto. Dissertação de Mestrado, Pontifícia Universidade Católica do Rio Grande do Sul, Porto Alegre, RS, Brasil.

Santos, J. H. F. D., \& Botelho, D. (2011). Análise comparativa de preços: variáveis influentes na percepção de vantagem de compra. RAM. Revista de Administração Mackenzie, 12(2), 145-168.

Schiffman, L. G. \& Kanuk, L. L. (2000). Comportamento do Consumidor. 6. ed. Rio de Janeiro: LTC.

Scott, J. A., Begley, A. M., Miller, M. R., \& Binns, C. W. (1991). Nutrition education in supermarkets: the Lifestyle 2000 experience. Australian Journal of Public Health, 15(1), 49-55.

Shoham, A., Kahle, L. R., \& Rose, G. M. (1995). Predicting price importance and deal proneness. European Advances in Consumer Research, 2, 258-263.

Solomon, M. R. (2016). o Comportamento do Consumidor: comprando, possuindo e sendo. 11. ed. Porto Alegre: Bookman.

Stankevich, A. (2017). Explaining the consumer decision-making process: Critical literature review. Journal of International Business Research and Marketing, 2(6), 7-14.

Tagnin, A. C. C. N., \& Giraldi, J. D. M. E. (2013). Atributos do produto valorizados no processo de decisão de compra de cerveja: um estudo qualitativo com universitários. Produto \& Produção, 14(1), 84-106.

Thøgersen, J., Pedersen, S., Paternoga, M., Schwendel, E., Aschemann-Witzel, J. (2017). How important is country-of-origin for organic food consumers? A review of the literature and suggestions for future research. British Food Journal, 119(3), 542-557.

Yan, D., Sengupta, J., \& Wyer Jr., R. B. (2014). Package size and perceived quality: The intervening role of unit price perceptions. Journal of Consumer Psychology, 24(1), 4-17

Yoo, B. \& Donthu, N. (2001). Developing and validating a multidimensional consumer-based brand equity scale. Journal of Business Research, 52(1), 1-14. 